\title{
DYNAMICS OF INFLUENCE OF COMPONENTS OF THE EXTERNAL ENVIRONMENT OF AVIATION ENTERPRISES FUNCTIONING IN COMPETITIVE MARKETS
}

\author{
Zarina Poberezhna'
}

\begin{abstract}
The purpose of the paper is research of the components of the external environment and assessment of its impact on the functioning of airlines in open markets. The article defines the essence of the concept of the external environment of the airline, in which the classical scheme highlights the environment of direct and indirect influence. The author notes that direct factors affect the activities of each individual airline separately, and indirectly - form general industry trends in competitive markets. In modern conditions, when the external environment of enterprises is extremely dynamic not only in Ukraine but also internationally, the problem of developing methodological approaches to assess the impact of macroeconomic factors on the activities of airlines is extremely relevant. Assessing the general trends in the aviation industry, it should be noted that the aviation industry is one of the few transport sectors that is developing gradually and has positive growth rates, despite the large wear of aircraft, which adversely affects the image component of most airlines. Methodology. Methods of scientific research are abstraction, grouping of data, study of time series, which made it possible to generalize the concept of environment, trends in the industry, assessment of the impact of individual factors on the development of the industry determined by correlation analysis. Results the analysis of the availability and degree of the relationship between the studied indicators made it possible to conclude that there is a strong relationship between the rate of domestic passenger traffic and population, the size of real GDP and income. Factors such as the political crisis, economic crisis, wars, terrorist acts, plane crashes, pandemics affect both domestic and global passenger traffic, which in turn is reflected in the financial condition of individual airlines. Practical implications. Analysis of the dynamics of the influence of components of the external environment of the functioning of aviation enterprises in competitive markets allows airlines to ensure sustainable development and economic activity without taking into account their economic activities. Thus, to ensure the effective operation of the enterprise in competitive markets and maintain competitiveness requires systematic management of the main resources of the enterprise. Value/originality. The author identified macroeconomic factors influencing the dynamics of the air transport industry, established the relationship between passenger traffic and global and national cataclysms (financial crises, political crises, plane crashes, pandemics, wars, etc.), substantiated the factors that caused the greatest impact on activities aviation enterprises.
\end{abstract}

Key words: external environment, factors of influence, airline, air transportation, cargo transportation, competitive markets, airlines.

\section{JEL Classification: L93}

\section{Introduction}

Competitive markets are the operating environment of an airline, which is represented by a large number of other entities, with their complex interconnections, infrastructure and special conditions of their activities. The importance of studying this environment is due to the fact that no airline does not carry out its business activities separately, but works in conjunction with

Corresponding author:

${ }^{1}$ National Aviation University, Ukraine.

E-mail: zarina_www@ukr.net

ORCID: https://orcid.org/0000-0001-6245-038X

ResearcherID: T-8659-2018 suppliers, credit and financial institutions, competitors, and therefore operates in the external environment, on the one hand adapting to it, and on the other - dictating conditions and establishing the rules of the game in its market niche. Since the airline is an open system consisting of individual elements that together ensure its stability, balance and ability to function and develop under internal and external influences, an important

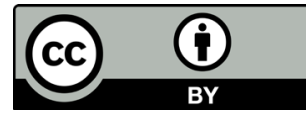

This is an Open Access article, distributed under the terms of the Creative Commons Attribution CC BY 4.0 
condition for its viability is the interaction with the external environment. Each airline, on the one hand, is under the constant influence of macroeconomic environmental factors, the dynamics of which are characterized by cyclicality and crisis, and on the other - reflect their own cycles of development and together form the entire socio-economic system, which determines the relevance of the study. The activity of airlines in difficult conditions depends on the goals and directions of strategic development chosen by the airline. In combination and proper functioning, airlines are able to ensure the effectiveness of control over both the external environment and the main and ancillary business processes of the airline, thereby ensuring the competitiveness of its services in both domestic and foreign markets. A key element that characterizes the relationship of all components of ensuring the effective functioning of the enterprise is a number of measures that allow you to create a clear database for understanding the availability of the necessary elements of the process of functioning.

Thus, the factors of the external environment should include: the dynamics of market development; competition; consumer perception of products (services) produced by the airline; availability of factors of production; speed of implementation of changes; purchasing power; type of consumers.

The factors of the internal environment should include: the potential for optimizing the ratio of "price / value"; degree of acceptance of changes; financial condition of the airline; technological development of the airline; quality of financial management; human resources; accumulated experience in change management and the history of the airline.

Thus, ensuring the operation of the airline in a complex, uncertain and dynamic environment is a modern, powerful and effective means of managing its activities. The operation of the airline in competitive markets is carried out under the influence of factors in the areas of its activities, justification of measures to eliminate obstacles to the development of the airline, in order to intensify promising areas of activity.

\section{Functioning of aviation enterprises in competitive markets}

To achieve the objectives in the article, the purpose of the analyze and compare some components of the external environment and assess its impact on the functioning of airlines in open markets. Methods of scientific research are abstraction, grouping of data, study of time series, which made it possible to generalize the concept of the external environment, trends in the industry, assessment of the impact of individual factors on the development of the industry determined by correlation analysis.

\subsection{The main factors of the external environment that influence of aviation enterprises}

Conducting research in the field of influence of certain environmental factors on the activities of airlines is given in the works of a large number of scientists, but in our opinion, it is necessary to single out O.V. Ushmarov (Ushmarova, 2006) who paid special attention to establishing patterns between the financial condition of airlines and environmental factors that affect it and E. D. Pakleeva (Pakleeva, 2016), who continued her scientific research and established a correlation between the dynamics of total revenue and the total debt burden of airlines. General trends in the aviation industry have been considered in the work of many researchers, but they are more descriptive in nature, in which there is no clear causal relationship between factors and performance factors.

Under the external for the airline we will consider the environment, which is represented by a set of market entities (located outside the enterprise) and the relationships between them, which have the ability to exert any influence on the activities of the airline.

The classic division of the external environment is its differentiation into the environment of direct and indirect influence. The environment of direct influence is usually understood as those agents that interact quite closely with the airline and cause a strong influence on it, while the environment of indirect impact is usually understood as a set of macroeconomic components that without direct interaction with the company also affect its vital activity.

The environment of direct influence of the airline should include, first of all its consumers (customers of goods, works and services, corporate and VIP-clients, etc.), that is all direct users of products, works and services of the enterprise, which can be both legal entities and individuals who use the goods, works and services of airlines for their own or organizational needs.

The external environment of indirect influence (macroenvironment) is a set of factors, factors and circumstances that do not directly affect the airline and ultimately have a positive or negative effect on its activities, and determine the general trends of the industry, which ultimately affects individual airlines.

Thus, it can be noted that direct factors have a direct impact on the activities of each individual airline, and indirect - form general industry trends and are larger. For example, among the economic ones should be distinguished: the level of inflation and bank interest, the level of income, the average annual growth of GDP per capita, the level of poverty and unemployment in the country and so on. Among the political ones: the annexation of the Autonomous Republic of Crimea and 
the Anti-Terrorist Operation in the East of the country, which negatively affected the attitude of the whole world community towards Ukraine and affected the financial condition of most sectors of the economy, including aviation. An example of international environmental factors is the pandemic of the COVID-19 virus, which has affected all world markets and intensified competition in them, and so on.

Before assessing the external factors influencing the activities of the airline should consider and understand its place in the overall transport system, and assess its level of popularity among domestic consumers, which is also an important factor in external influence on consumption of goods, works and services. Based on data (State Statistics Service of Ukraine, 2018), we can conclude that the place of air transport in the overall structure of passenger traffic is quite small, which increases from $0.03 \%$ in 1995 to $0.3 \%$ in 2019 , but Ukrainians have this the type of transport is not popular enough, which can be explained by its high cost and mentality of the population, which was formed in the Soviet Union. The largest share falls on road transport, which fluctuated in different years - the lowest value was in 1998 - 31.0\% (2403424.6 thousand passengers), and the highest in $2010-54.4 \%$ (3726288.6 thousand passengers).

\subsection{Dynamics of influence of components of the external environment of aviation enterprises}

Air transport, although it has a positive dynamics in terms of increasing cargo traffic from 19 thousand tons in 1995 to 92.6 thousand tons in 2019, still occupies a small share in traffic. This is due to the high cost of such transportation, low popularity among consumers and the mentality of the nation. In this regard, the share of air cargo transported is at the level of $0.01 \%$ in 2019 . The largest number of cargo in our country is transported by road, so in 1995 was transported 1816401.0 thousand tons - this is the maximum, and the minimum was in $2000-$ 938916.1 thousand tons of cargo. In conclusion, it can be noted that in the domestic market there is strong competition from air transport with other types, such as rail and road.

According to (State Aviation Service of Ukraine) and (Figure 1), it is seen that the number of transported passengers by aviation companies is growing as a whole (from 5131.1 thousand people in 2009 to 13705.8 thousand people in 2019) and international (from 4135.9 thousand people in 2009 to 12547 thousand people in 2019) and domestic transportation (from 995.2 thousand people in 2009 to 1158.6 thousand people in 2019). In 20182019, the transportation of passengers, cargo and mail was carried out by 34 domestic airlines, which performed 100.3 thousand flights and 103.3 thousand flights, respectively. Which is 55.8\% more in 2019 than in 2015.

Among domestic consumers (Figure 1), international air transportation is in greater demand, because in 2019 it accounted for $91.5 \%$ of all air transportation, although since 2016 domestic air transportation is becoming increasingly important, and in 2018 the industry reached the level of 2009 for such transportation slightly exceeding this figure. Thus, in 2019 the number of transported persons amounted to 1158.6 thousand people, and in 2009 - 995.2 thousand people. The increase was 163.4 thousand people (16.4\%). Comparing the data of 2019 and 2018, in 2019 the increase was by 75.7 thousand people $(7.0 \%)$. The increase in passenger traffic had a positive effect on the occupancy of seats in aircraft on domestic scheduled flights during 2017-2018 from 73.5\% to $79.3 \%$ respectively, in $2018-2019$ it amounted to $75.9 \%$.

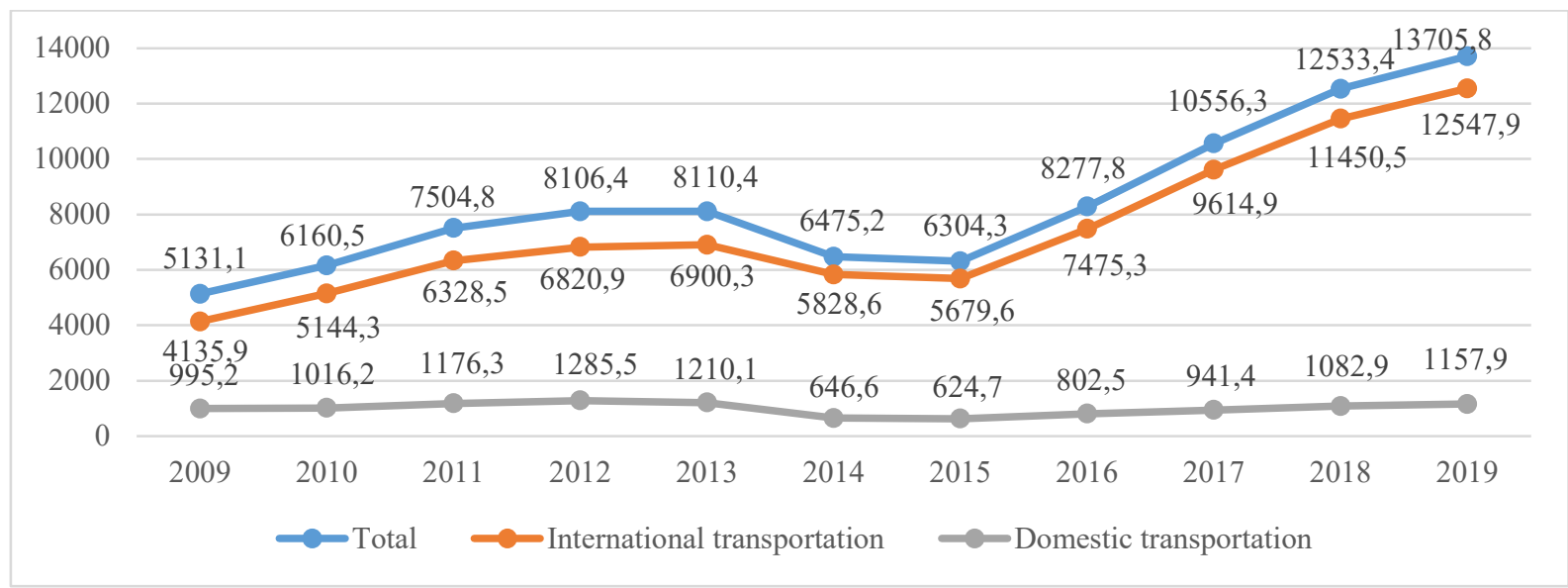

Figure 1. Dynamics of passenger traffic by air transport of Ukraine 2009-2019 (thousand people)

Source: Built on the basis of data (State Aviation Service of Ukraine) 
Realizing the general dynamics of the industry, the increase and decrease in different years of passenger and freight traffic, we should pay attention to what external factors have caused the greatest impact on the performance of aviation companies.

The importance of studying the external factors influencing the micro and macro environment on the activities of airlines is described by Ushmarova O. V. in the work "Restructuring of the airline in the context of the sectoral structural crisis", in which it established a number of patterns between the financial condition of the airline and external factors affecting their activities, among which were the following: political instability, including wars and terrorist acts, macroeconomic factors (change in GDP, income level) and the dynamics of exchange rates and oil prices (Ushmarova, 2006; Pakleeva, 2016).

Let's analyze the dynamics of the total passenger traffic of Ukrainian airlines in the period 1995-2018 which shows that the largest declines in passenger growth occurred during the crisis of 1997-1998, which arose in Ukraine against the background of the collapse of the Soviet Union, independence and the transition from the ruble to the hryvnia in 1996, which together caused hyperinflation, negatively affected, though not large at the time passenger traffic. Figure 2 shows the flow of domestic air carriers in 1995-2018.

The decline of 2004-2005 was caused by the "Orange Revolution" in the countries against the background of the political crisis and the crisis of power. The slowdown in passenger growth in 2008 was due to the rapid depreciation of the hryvnia due to the global financial crisis. The critical minimum was reached in 2014 due to a number of political and economic upheavals. First, the annexation of Crimea, and secondly, the anti-terrorist operation in eastern Ukraine, the bankruptcy of most private banks. The onset of the political crisis in the country and economic instability led to a downward trend in passenger traffic in 2017-2019. In general, it is clear that the decline in passenger traffic is directly related to the crisis in the economy and political situation in the country. In addition, in 2020 it is possible to predict the negative dynamics of passenger traffic and cargo volumes due to the global pandemic caused by COVID-19.

Paying attention to (Figure 3) it can be noted that a similar situation developed with the flow of goods in 1995-2018. However, the sphere of cargo transportation turned out to be more sensitive than the sphere of passenger traffic. Thus, we observe sharper peaks of ups and downs, which are caused not only by national factors but also by factors of international importance.

A full understanding of the dynamics of changes in international and domestic passenger flows and identifying the impact of key events in Ukraine and the world (economic crises, political conflicts, hostilities, terrorist acts, plane crashes, etc.) can be obtained from (Figure 3).

As can be seen from (Figure 4) that 1997-1998 was marked in the world by the Asian crisis, which ripened until 1997 and led to the rapid collapse of stock indices in Southeast Asia, together with large government and corporate debts, most affected Indonesia, South Korea

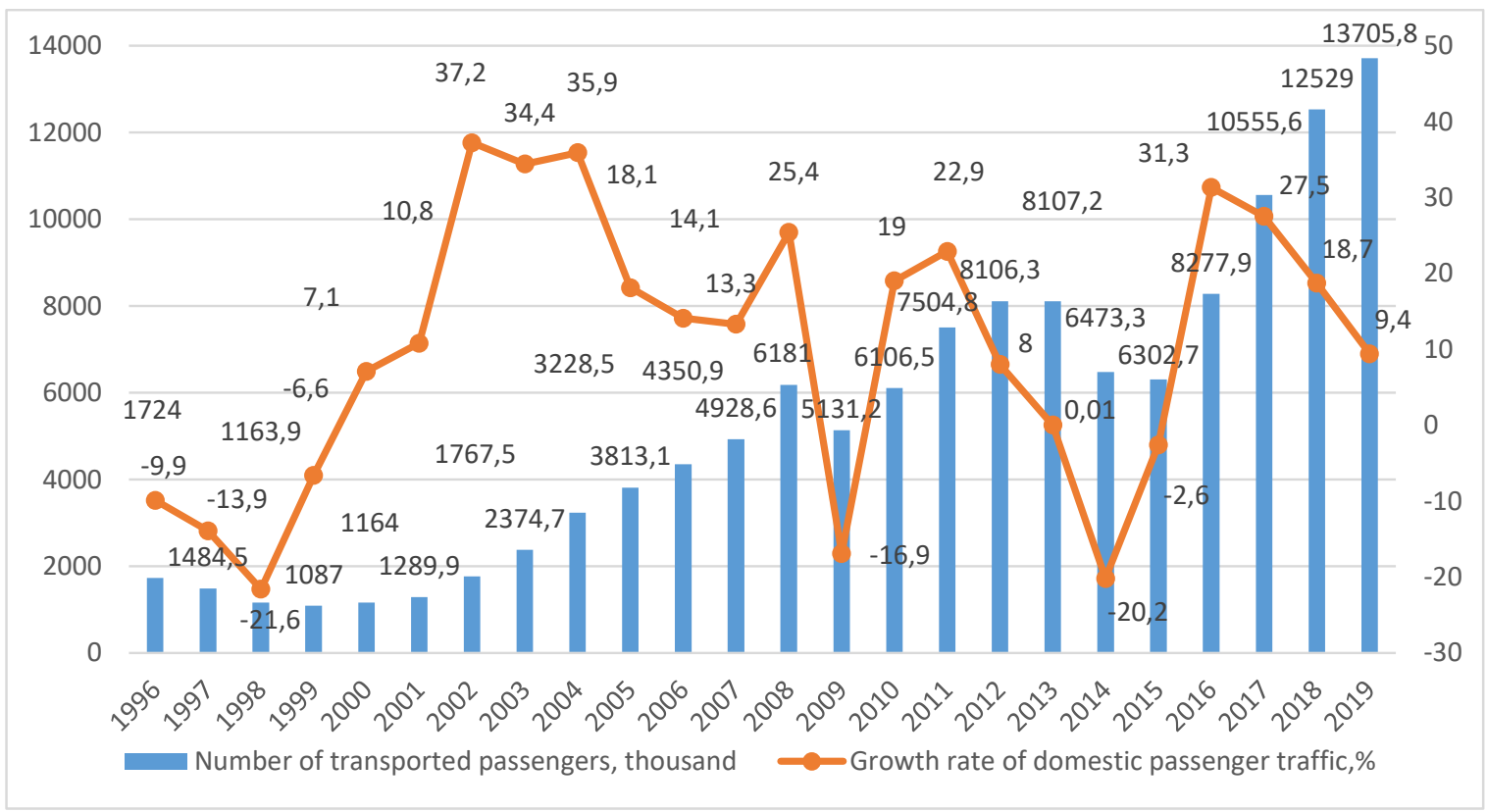

Figure 2. Passenger traffic of domestic air carriers 1995-2018

Source: Built on data (State Aviation Service of Ukraine) 
Vol. 2 No. 3, 2021

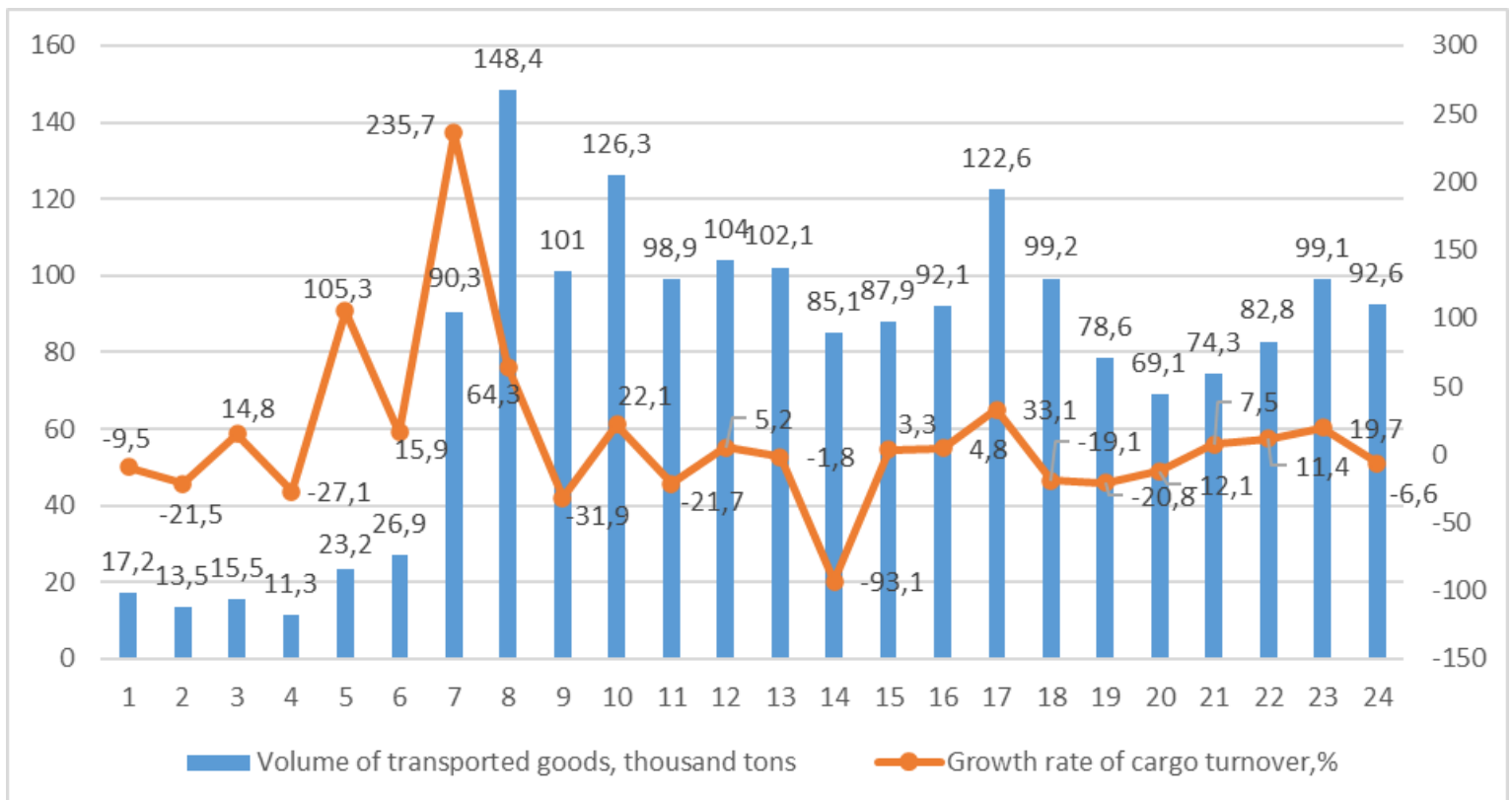

Figure 3. Cargo flow of domestic air carriers 1995-2018

Source: Built on data (State Aviation Service of Ukraine)

and Thailand (Statistic Asian crisis, 1997-2001). The terrorist attack of September 11, 2001 in America negatively affected global passenger traffic, as shown in Figure 4, but did not affect the domestic carriage of passengers.

Global and national passenger traffic in 2003 was determined by Severe Acute Respiratory Syndrome / SARS - a viral infectious disease, a special variant of coronavirus infection with a predominance of airborne transmission of infection with respiratory damage and, in severe cases, with the appearance of atypical pneumonia (Raymond, Wongand Alan, and $\mathrm{Wu}, 2003)$. In Ukraine, as already mentioned, this decline was caused by the consequences of the conflict with Russia.

The grand recession of 2007-2009 was caused by the great recession of the entire world economic system, which affected all world economies, and is called the "bail crisis" (Great Recession, 2017), which is also reflected in global and national passenger flows. A series of global and domestic upheavals led to a decline in passenger traffic in 2014, which was first caused by the European migration crisis and the imposition of economic and political sanctions against the Russian Federation, lower fuel prices on world markets and hostilities in Syria. Summing up the

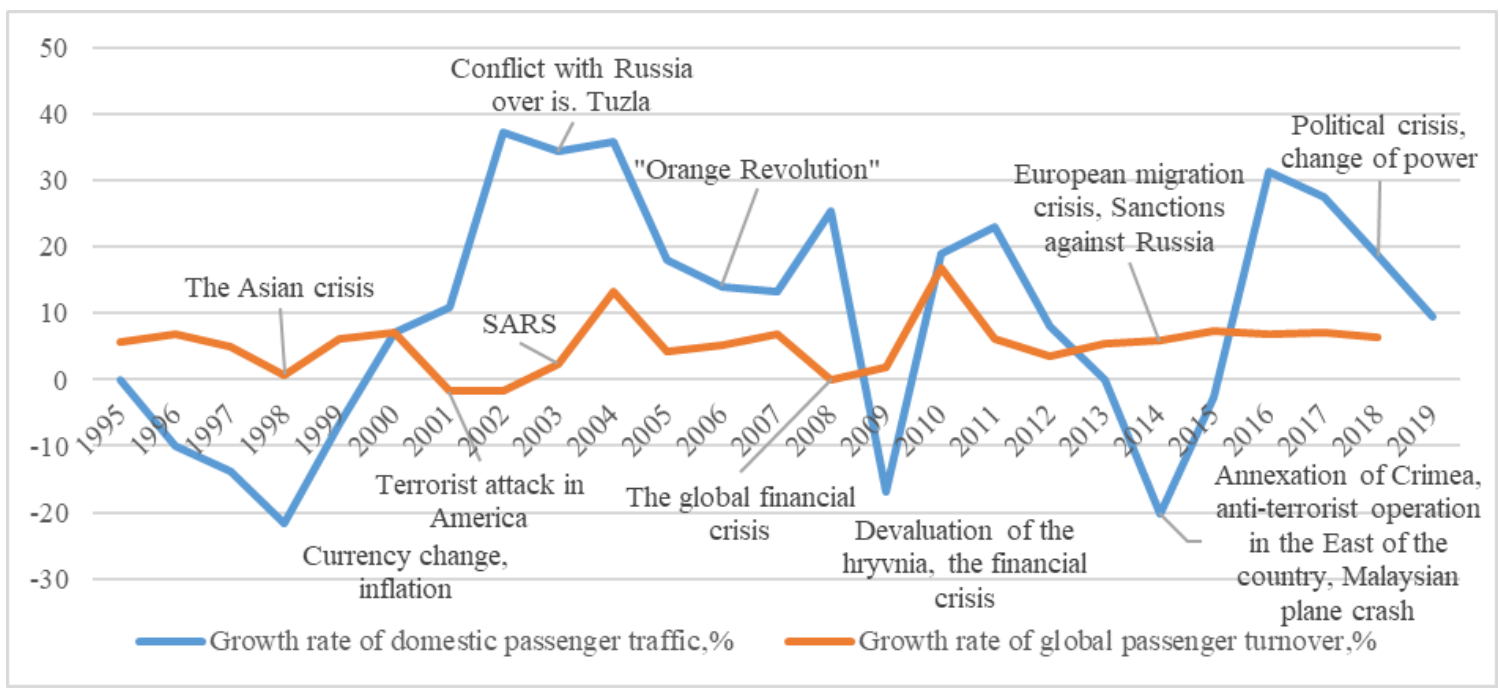

Figure 4. Dynamics of global and Ukrainian passenger traffic and key events in the country and the world 1995-2019

Source: Built on the basis of data (IATA Industry Statistic; Asian crisis 1997-2001; Raymond, Wongand Alan, Wu, 2003; Great Recession, 2017; Conflict on the island of Tuzla, 2003; State Aviation Service of Ukraine) 


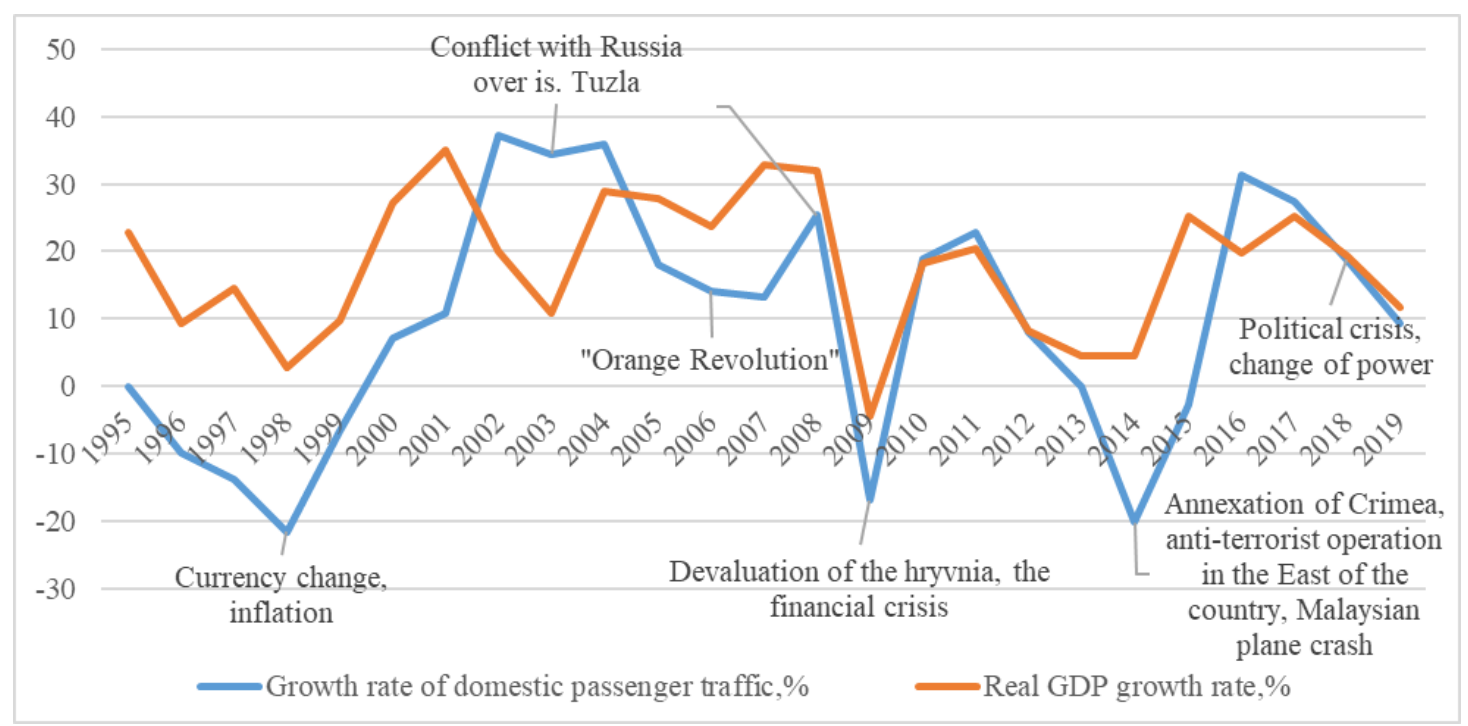

Figure 5. Dynamics of national regular passenger traffic and real GDP of Ukraine 1995-2019

Source: Built on the basis of data (Asian crisis 1997-2001; Raymond, Wongand Alan, Wu 2003; Great Recession, 2017; Gross Domestic Product, 1996-2026; Conflict on the island of Tuzla, 2003; State Aviation Service of Ukraine)

general trend, we note that the factors of the crisis in the national economy and political life of the country led to a sharper herd, especially in 2014, compared to global passenger traffic.

Let's analyze the growth rate of real GDP in Ukraine and the growth rate of national passenger traffic. Following the dynamics of passenger traffic growth and real GDP, (Figure 5) it can be noted that the peaks of their growth and decline are quite closely intersected. All the above-mentioned crises in Ukraine are directly related to GDP declines, but there was another circumstance that negatively affected GDP growth in 2003 - the internal crisis of Ukrainian-
Russian relations, which was caused by the beginning of construction of a dam off the coast of Tamansky peninsula to the Ukrainian island of Tuzla in order to join it to the mainland of Russia (Conflict on the island of Tuzla, 2003). Special mention should be made of the downing of a Boeing 777 of Malaysia Airlines near Donetsk in 2014.

In (Figure 6) presents the dynamics of national passenger traffic and average annual wages in Ukraine 1995-2019.

The figure shows that in general the growth of the average annual wage has a significant impact on domestic passenger traffic, small differences can be

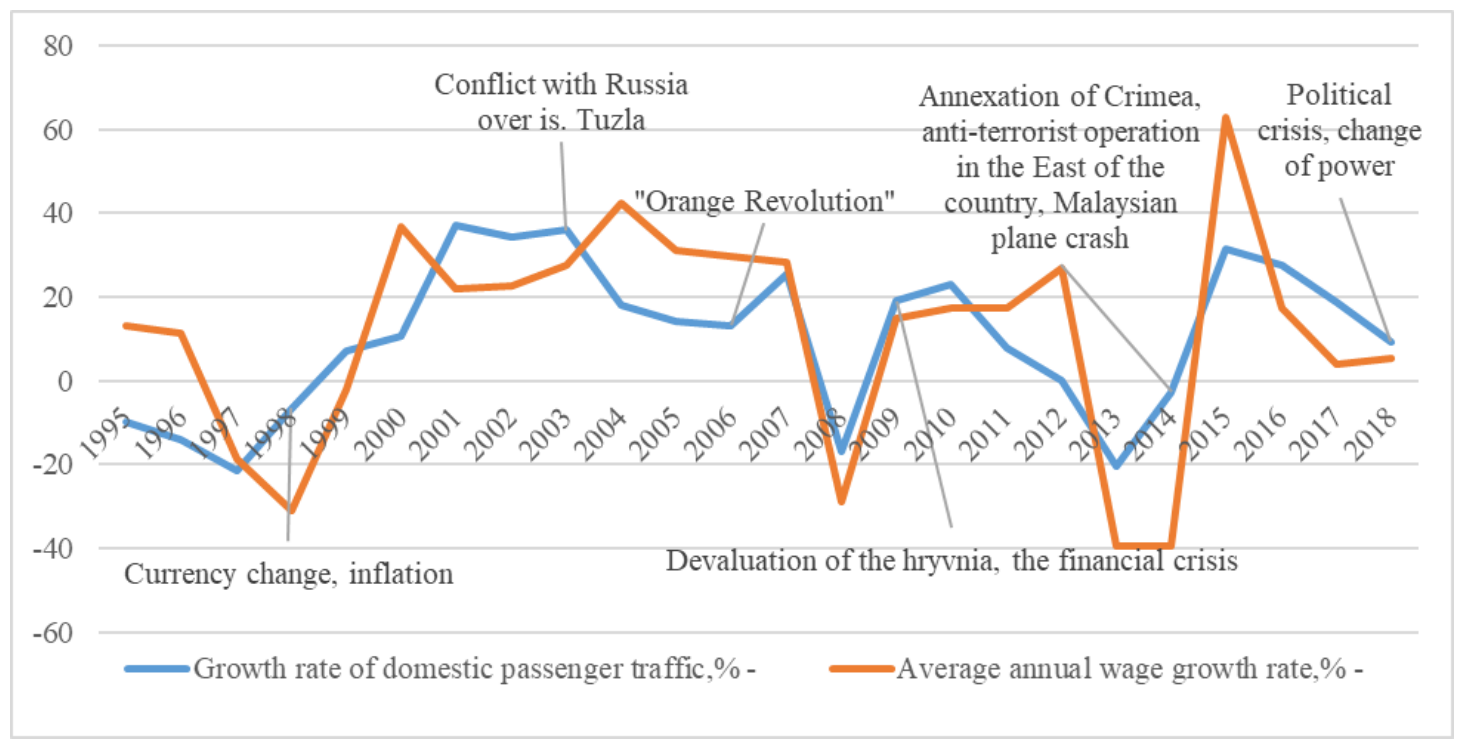

Figure 6. Dynamics of domestic regular passenger traffic and average annual wages in Ukraine 1995-2018

Source: Built on the basis of data (Asian crisis 1997-2001; Raymond, Wongand Alan, Wu 2003; Great Recession, 2017; Conflict on the island of Tuzla, 2003; Income of population in Ukraine, 2012-2019; State Aviation Service of Ukraine) 
explained by the following: the availability of savings and wages in "envelopes" does not prevent sharp peaks and gently affects overall passenger traffic.

A correlation coefficient was calculated to determine the presence and extent of relationships between indicators. There is a strong direct correlation between the total passenger flow of domestic airlines and the real GDP of Ukraine. The correlation coefficient is equal to 0.962770233 .

There is also a strong relationship between aggregate passenger traffic and average annual wages, with a correlation coefficient of 0.878802287 . However, there is not a strong direct relationship between the growth rate of passenger traffic and the growth rate of the average annual wage (correlation coefficient is 0.697257208 ), this may be due primarily to the above factors of "shadow wages" and the fact that data on domestic passenger traffic includes domestic and international transportation by airlines that are actually registered in Ukraine.

Despite the growing availability and popularity of air transportation, establishing ties with Europe and the world, in times of global crises and domestic shocks, against the background of declining average annual incomes, there is a decrease in the number of international air travel.

More details in (Figure 7) presents: pre-tax financial result and net financial result of aviation enterprises, as well as the dynamics of these indicators. It can be seen that both the pre-tax financial results and the net financial result of airlines have fluctuated significantly over the past 8 years, especially during the crisis of 2014-2015.

Comparing the graphs of the dynamics of indicators, we can conclude that the most sensitive indicator of the financial condition of airlines is the growth rate of pre-tax financial results. The greatest value of the indicators came in 2016, when airlines began to emerge from the crisis, but at the end of 2017, the net financial result of aviation companies was negative.

\section{Results and discussions}

Summing up the research, we note that the external environment of the airline is an environment that is outside it and according to the classical approach is divided into an environment of direct and indirect influence. The environment of direct influence includes: consumers, competitors, partners and government agencies and authorities. The environment of indirect influence includes: economic, scientific and technical, political and legal, socio-cultural, international and environmental environment.

Assessing the overall place of airlines in the total cargo and passenger traffic, it was noted a very small share of it among other transport companies. Air transport in the overall structure of passenger traffic occupies a fairly small share, which increases from $0.03 \%$ in 1995 to $0.3 \%$ in 2019 . It should also be noted that air transport, although it has a positive trend in increasing traffic cargo from 19 thousand tons in 1995 to 92.6 thousand tons in 2019, but also occupies a small share.

\section{Conclusions}

The research identified the most influential reasons for this situation: first - the high cost of such transportation, and secondly, the unpopularity of this mode of transport is caused by the mental mood of citizens, and thirdly, the lack of developed infrastructure

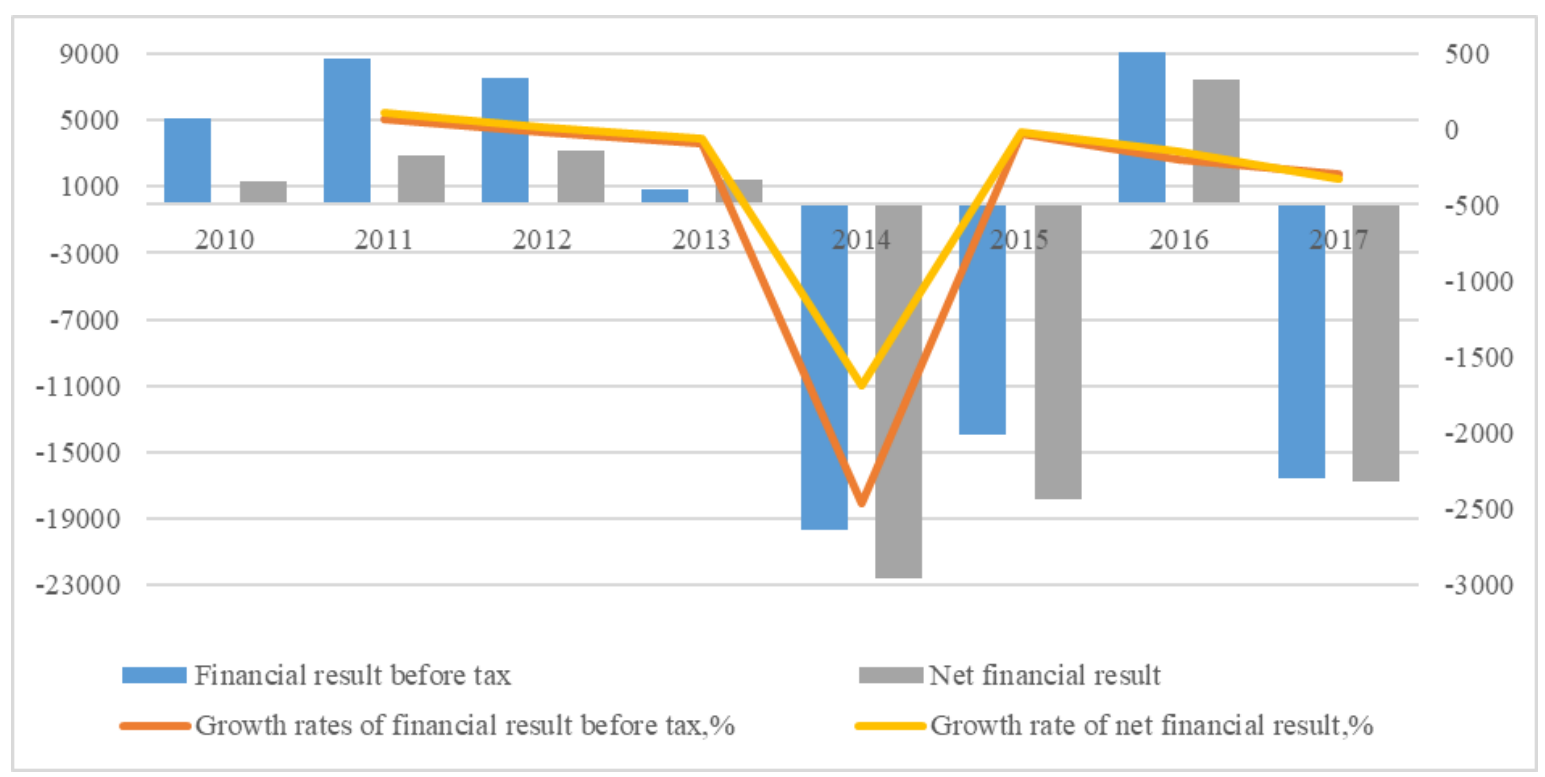

Figure 7. Dynamics of pre-tax financial results and net financial result of domestic airlines in 2010-2017

Source: Built on the basis of data (Ukrstat Ukraine, 2013-2018) 
due to lack in most cities suitable for use at airports and aerodromes.

Paying attention to macroeconomic factors influencing the dynamics of the industry, the author established the relationship between passenger traffic and global and national cataclysms (financial crises, political crises, plane crashes, pandemics, wars, etc.), which suggests that the factors of indirect influence (macroeconomic) have a strong influence on domestic and global general trends in passenger and freight traffic. After conducting a correlation analysis, a close direct correlation was found between the total passenger flow of domestic airlines and the real GDP of Ukraine, the correlation coefficient is equal to 0.962770233 .

So, summarizing the results of the study, we can note that the early detection of the most important factors that affect the company, allows its management to develop appropriate decisions on action in changing conditions. There is a big one the number of environmental factors that have a direct or indirect effect on the state and development of the aviation enterprise. Based on the study, the most important factors of the external environment of the aviation enterprise with their division into factors of direct and indirect actions, and a classification of factors is proposed external environment on various grounds.
In the further separation of the factors of negative influence, monitoring and forecasting of which are available the most important actions for the aviation enterprise. Any analysis can not reliably predict the future, it is impossible to take into account all the changes in the external environment of the aviation enterprise. Ago it is necessary to develop and implement measures to adapt the aviation enterprise to the external environment. The developed measures will be based on the principle of adaptability, according to which the company is considered as an adaptive system, ie one that retains performance in case of unforeseen changes in its goals and characteristics or the environment by changing the algorithm or finding the optimal state. Adaptability, constant adaptation of the system to external factors is achieved through feedback information communication and immediate adequate response to changes that occur.

The objective function of adaptation is to achieve the strategic goals of the aviation enterprise by flexibly adapting the internal capabilities of the aviation enterprise to changes in the external environment. Monitoring is aimed at constant monitoring of current and new information, disclosure of causes changes in the state of the studied factors and prediction of trends in their development.

\section{References:}

Ushmarova, O. V. (2006). Specifics of airline restructuring in a crisis. Economic analysis: theory and practice, 19(76), 43-51.

Pakleeva, E. D. (2016). Estimation of influence of factors of external environment on activity of the Russian airlines. Modern scientific researches and innovations, 6. Available at: http://web.snauka.ru/issues/2016/06/68396

International Air Transport Association Fact Sheet Industry Statistics. Available at: https://data.worldbank.org/ indicator/IS.AIR.PSGR

Asian crisis 1997-2001. Available at: https://neftegaz.ru/news/finance/334116-1997-2001-aziatskiy-krizis/

Raymond, S. M., Wongand Alan, \& Wu (2003). Haematological manifestations in patients with severe acute respiratory syndrome: retrospective analysis BMJ (Clinical research ed.), vol. 326 (7403), pp. 1358-1362.

Great Recession. Available at: https://www.history.com/topics/21st-century/recession

Gross domestic product of Ukraine. Available at: https://www.statista.com/statistics/296140/ukraine-grossdomestic-product/

Conflict on the island of Tuzla. Available at: https://www.jnsm.com.ua/h/0929N/

Income of the population of Ukraine. Available at: http://www.ukrstat.gov.ua/operativ/operativ2005/gdn/ dvn ric/dvn\%20 u/dvn u.htm

Petrenko, I. (ed.) (2018). State Statistics Service of Ukraine: Transport and Communications of Ukraine, Statistical Collection.

State Aviation Service of Ukraine. Available at: https://avia.gov.ua/pro-nas/statistika/operativna-informatsiya/

Activities of business entities. Available at: http://www.ukrstat.gov.ua/druk/publicat/Arhiv_u/09/Arch_ dsg_bl.htm 